\title{
Præsident Putins tale ved annekteringen af Krim
}

Den 18. marts talte Præsident Putin til medlemmerne af Statsdumaen ovenpå udviklingen i Krim. I talen betonede han det historiske forhold mellem Krim og Rusland.

God dag, ærede medlemmer af Føderationsrådet, ærede medlemmer af Statsdumaen, ærede repræsentanter for republikken Krim og Sevastopol - de er her blandt os, borgere i Rusland, indbyggere på Krim og i Sevastopol!

Ærede venner, i dag er vi samlet omkring et spørgsmål, som har vital, historisk betydning for os alle sammen. Den 16. marts var der folkeafstemning på Krim, og den foregik i fuld overensstemmelse med de demokratiske procedurer og folkeretlige normer.

Over $82 \%$ af vælgerne deltog i afstemningen. Over $96 \%$ stemte for en genforening med Rusland. Tallene er yderst overbevisende. For at forstå, hvorfor der blev truffet netop dette valg, er det tilstrække- ligt at kende Krims historie og vide, hvad Rusland har betydet og betyder for Krim og Krim for Rusland.

På Krim vidner bogstavelig talt alt om vores fælles historie og stolthed. Her ligger det gamle Khersones, hvor den hellige fyrst Vladimir modtog dåben. Hans åndelige bedrift - omvendelsen til den ortodokse tro - skabte det fælles kulturelle, værdimæssige og civilisatoriske grundlag, som forener folkene i Rusland, Ukraine og Hviderusland. På Krim er de russiske soldater begravet, hvis tapperhed i 1783 bragte Krim ind i det russiske imperium. Krim er Sevastopol, den legendariske by med dens skæbnefyldte historie, fæstningsbyen samt hjemstedet for den russiske sortehavsflåde. Krim er Balaklava og Kertj, Malákhovhøjden og Sapúnhøjden. Hvert af disse steder er helligt for os, det er symboler på russisk militær berømmelse og heltemod uden sidestykke.

Krim er også en unik blanding af forskellige folkeslags kulturer og traditioner. Og dermed ligner den i høj grad det store Rusland, hvor ikke et eneste folkeslag er

Ud over de her nævnte var alle regeringsmedlemmerne til stede. Blandt repræsentanterne for civilsamfundet sås bl.a. nationalbankdirektøren Elvira Nabiullina, den tidligere ministerpræsident og udenrigsminister Jevgenij Primakov og filminstruktøren, skuespilleren og formanden for det russiske filmforbund Nikita Mikhalkov og flere andre, der tilhører eliten i Rusland. Herudover sås lederne af tre af de fire traditionelle trossamfund i Rusland, nemlig overmuftien Talgat Tadzjuddin, overrabineren Berl Lazar og de russiske buddhisters leder Damba Ajusjejev. Den Russiske Ortodokse Kirke var repræsenteret af biskoppen af Krutitsy og Kolomna Juvenalij og ikke af patriark Kirill. Ifølge en russisk kommentator skyldtes det, at patriarken ved sin tilstedeværelse ved Putins krimtale ville komme til at godkende Krims tilslutning til Rusland og dermed risikere at miste Den Ukrainske Ortodokse Kirke under Moskvas Patriarkat, og den udgør en meget stor del af dette. 
For os er det vigtigere, at denne beslutning åbenlyst krænkede de dengang gældende forfatningsmæssige normer. Spørgsmålet blev afgjort bag kulisserne i en snæver kreds. I den totalitære stat var der naturligvis ingen, der spurgte Krims og Sevastopols indbyggere om noget. De blev blot stillet over for en kendsgerning. Folk undrede sig naturligvis også dengang over, hvorfor Krim pludselig var blevet en del af Ukraine. Men strengt taget blev denne beslutning - og det skal siges ligeud, det forstår vi alle sammen - opfattet som en formalitet, for områderne blev jo overført inden for rammerne af ét stort land. Dengang kunne man bare ikke forestille sig, at Ukraine og Rusland kunne blive skilt og blive forskellige stater. Men det skete.

Det, der forekom usandsynligt, blev desværre en realitet. USSR gik i opløsning. Begivenhederne udviklede sig så hurtigt, at kun de færreste borgere forstod, hvor dramatiske begivenhederne var, og hvilke følger de ville få. Mange mennesker såvel i Rusland som i Ukraine og de andre republikker håbede, at Fællesskabet af Uafhængige Stater (SNG), der opstod dengang, ville blive en ny form for et fælles statssystem. Man lovede dem jo såvel en fælles valuta, et fælles økonomisk rum som fælles væbnede styrker, men alt dette forblev kun løfter, og det store land blev ikke til noget. Det var først, da Krim pludselig befandt sig i en anden stat, at Rusland mærkede, at det ikke kun var blevet bestjålet, men udplyndret.

Samtidig må vi også åbent erkende, at Rusland ved at sætte gang i paraden af suveræniteter selv bidrog til Sovjetunionens sammenbrud, og at vi ved udformningen af USSR's opløsning glemte såvel Krim som Sortehavsflådens hovedbase Sevastopol. Millioner af russere gik i seng i ét land, men vågnede op i forskellige andre og blev med ét nationale mindretal i de tidligere sovjetrepublikker, og det russiske folk blev et af de største, hvis ikke det største folk i verden, der er delt af grænser.
I dag mange år senere har jeg hørt, at krimborgere for nylig har sagt, at de dengang i 1991 simpelthen blev overdraget som en sæk kartofler. Det er det svært at være uenig i. Og den russiske stat, hvad med den? Hvad med Rusland? Det bøjede hovedet og fandt sig i denne fornærmelse og bed den i sig. Vores land befandt sig dengang i en så vanskelig situation, at det ganske simpelt ikke reelt kunne forsvare sine interesser. Men folk kunne ikke affinde sig med denne himmelråbende historiske uretfærdighed. I alle disse år rejste såvel borgere som mange offentlige personer dette emne flere gange, idet de sagde, at Krim var oprindeligt russisk område og Sevastopol en russisk by. Ja, alt det forstod vi udmærket, følte i hjerte og sjæl, men vi måtte gå ud fra de foreliggende realiteter og på et nyt grundlag opbygge gode naboskabsforbindelser med det uafhængige Ukraine. Og forholdet til Ukraine, til det ukrainske broderfolk har været, er og vil uden nogen overdrivelse altid være det allervigtigste for os.

I dag kan vi tale åbent om det, og jeg vil gerne delagtiggøre Dem i detaljerne i de forhandlinger, der fandt sted i begyndelsen af 2000'erne. Dengang bad Ukraines præsident Kutjma mig om at fremskynde processen med at få fastlagt den russisk-ukrainske grænse. Indtil da var denne proces praktisk talt ikke kommet ud af stedet. Rusland syntes at have anerkendt Krim som en del af Ukraine, men der blev ikke ført nogen forhandlinger om grænsedragningen. Selvom jeg var klar over alle vanskelighederne i denne proces, gav jeg ikke desto mindre straks ordre til de russiske myndigheder om at sætte gang i dette arbejde - arbejdet med at fastlægge grænsen, så alle kunne forstå, at vi ved at gå med til grænsedragningen de facto og de jure anerkendte Krim som ukrainsk territorium og derved helt lukkede dette spørgsmål. 


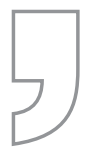

Jeg kan godt forstå, hvorfor folk i Ukraine ønskede forandring. Under årene med selvstændighed havde de fået nok af myndighederne og var simpelthen blevet dødtrætte af dem.
Vi imødekom Ukraine ikke kun, hvad angik Krim, men også med hensyn til et så vanskeligt emne som grænsedragningen i Det Azovske Hav og Kertj-strædet. Hvad var vores udgangspunkt dengang? Vi gik ud fra, at det vigtigste for os var et godt forhold til Ukraine, og at det ikke skulle være gidsel for udsigtsløse territoriale tvister. Men i denne forbindelse regnede vi selvfølgelig med, at Ukraine ville blive ved med at være vores gode nabo, at russerne og de russisktalende borgere i Ukraine, især i den sydøstlige del af landet og på Krim, ville leve i en venligsindet, demokratisk og civiliseret stat, at deres legitime interesser ville blive garanteret i overensstemmelse med folkerettens normer.

Men situationen udviklede sig anderledes. Gang på gang blev der gjort forsøg på at fratage russerne deres historiske hukommelse, undertiden også deres modersmål, og at gøre dem til genstand for tvungen assimilation. Og russerne såvel som andre borgere i Ukraine led naturligvis under den permanente politiske og statslige krise, som har rystet Ukraine i over 20 år.

Jeg kan godt forstå, hvorfor folk i Ukraine $ø$ nkkede forandring. Under årene med selvstændighed havde de fået nok af myndighederne og var simpelthen blevet dødtrætte af dem. Præsidenter, premierministre, parlamentsmedlemmer kom og gik, men deres holdning til deres land og deres folk ændrede sig ikke. De "malkede" Ukraine og sloges indbyrdes om beføjelser, aktiver og pengestrømme. Og magthaverne var ikke særlig interesserede $\mathrm{i}$, hvad almindelige mennesker levede af og hvordan, herunder hvor- for millioner af ukrainske borgere ikke så nogen perspektiver for sig i landet og var nødt til at rejse til andre lande som daglejere. Jeg vil gerne understrege, at de ikke tog til nogen Silicon Valley, men netop på arbejde som daglejere. Alene i Rusland arbejdede der næsten tre millioner af dem sidste år. Ifølge nogle skøn udgjorde deres løn i 2013 i Rusland over 20 milliarder dollar eller omkring $12 \%$ af Ukraines BNP.

Jeg gentager, at jeg udmærket forstår dem, der kom ud på Majdan (Uafhængighedspladsen i Kijev - o.a.) med fredelige paroler mod korruption, ineffektiv statslig administration og fattigdom. Retten til fredelig protest, demokratiske procedurer og valg eksisterer netop med henblik på at skifte de myndigheder ud, folk ikke bryder sig om. Men de, der stod bag de seneste begivenheder i Ukraine, forfulgte andre mål: de forberedte endnu et statskup, planlagde at tage magten uden at lade sig standse af noget. De iværksatte terror, mord og pogromer. Det var først og fremmest nationalister, neonazister, russofober og antisemitter, der gennemførte kuppet. Netop de bestemmer i mange henseender endnu den dag i dag livet i Ukraine.

Det første, de nye såkaldte "myndigheder" gjorde, var at fremsætte et skandaløst lovforslag om revision af sprogpolitikken, som var en direkte krænkelse af de nationale mindretals rettigheder. De udenlandske sponsorer af disse nuværende "politikere", de nuværende "myndigheders" kuratorer, satte ganske vist øjeblikkeligt en stopper for initiativtagerne til dette forehavende. Man må medgive dem, at de er kløgtige folk, 
som forstår, hvad forsøgene på at opbygge en etnisk ren ukrainsk stat vil føre til. Lovforslaget blev henlagt, men klart reserveret til fremtiden. At det faktisk findes, forties - man regner åbenbart med, at den menneskelige hukommelse er kort. Men det står allerede helt klart for alle, hvad de vil i fremtiden, disse ukrainske idemæssige arvtagere til Bandera - Hitlers håndlanger under Anden Verdenskrig.

Det står også klart, at der endnu ikke er nogen legitim udøvende magt i Ukraine, at der ikke er nogen at tale med. Mange statsorganer er overtaget af usurpatorer, som intet kontrollerer i landet, og selv det vil jeg gerne understrege - ofte kontrolleres af yderligtgående elementer. Man kan endda kun blive modtaget af visse ministre i den nuværende regering med tilladelse fra de militante på Majdan. Det er ikke en spøg, men dagens realiteter.

De, der gjorde modstand mod kuppet, blev straks truet med repressalier og straffeoperationer. De første i rækken i denne forbindelse var naturligvis Krim, det russisksprogede Krim. I denne forbindelse henvendte borgerne på Krim og i Sevastopol sig til Rusland og bad det om at forsvare deres rettigheder og beskytte deres liv og forhindre det, der skete og stadig sker i Kijev, Donetsk, Kharkov og i andre ukrainske byer.

Vi kunne naturligvis ikke lade være med at efterkomme denne anmodning, vi kunne ikke lade Krim og dens beboere være alene i nødens stund - alt andet ville have været forræderi.

Først måtte vi hjælpe med at skabe betingelser for en fredelig og fri meningstilkendegivelse, for at krimborgerne selv kunne bestemme deres skæbne for første gang i historien. Men hvad hører vi i dag fra vores kolleger i Vesteuropa og Nordamerika? De siger, at vi krænker folkerettens normer. For det første er det godt, at de dog er kommet i tanke om, at der er noget, der hedder folkeret - tak for det, bedre sent end aldrig.
Og for det andet det allervigtigste: hvad er det, vi krænker? Det er rigtigt, at Den Russiske Føderations præsident har fået lov af parlamentets øverste kammer til at bruge de væbnede styrker i Ukraine. Men denne ret har han strengt taget ikke engang brugt endnu. Ruslands væbnede styrker er ikke rykket ind på Krim, for de var der i forvejen $\mathrm{i}$ henhold til en international aftale. Ja, vi har forstærket vores kontingent, men i den forbindelse - og det vil jeg gerne understrege, så alle ved det og har hørt det har vi ikke overskredet det normerede personeltal for vores væbnede styrker på Krim, og det udgør omkring 25.000 mand - det var der simpelthen ikke behov for.

Endvidere. Da Krims Øverste Sovjet erklærede uafhængighed og udskrev folkeafstemning, henviste den til De Forenede Nationers Pagt, hvori der tales om en nations ret til selvbestemmelse. Jeg vil i øvrigt lige minde om, at Ukraine, da det bebudede sin udtræden af USSR, selv gjorde det samme, næsten ord for ord. Ukraine benyttede sig af denne ret, men krimborgerne nægtes den. Hvorfor?

Desuden henviste Krims myndigheder til kendt præcedens i Kosovo, et præcedens vores vestlige partnere selv har skabt, som man siger med deres egne hænder, i en situation, der er absolut analog til den på Krim, og anerkendte Kosovos udtræden af Serbien som legitim og demonstrerede for alle, at der ikke kræves nogen tilladelse fra et lands centrale myndigheder til en ensidig uafhængighedserklæring. FN's Internationale Domstol er på grundlag af FN-Pagtens artikel 1, stk. 2 enig heri og bemærkede i sin resolution af 22. juli 2010 følgende. Jeg citerer ordret: "Der kan ikke udledes noget generelt forbud mod en ensidig uafhængighedserklæring af Sikkerhedsrådets praksis", og videre: "Den generelle folkeret indeholder ikke noget anvendeligt forbud mod udråbelse af uafhængighed." Alt er krystalklart, som man siger. 
Jeg kan ikke lide at bruge citater, men jeg kan alligevel ikke lade være; her er endnu et uddrag af et officielt dokument, denne gang USA's skriftlige memorandum af 17 . april 2009, fremlagt for den samme Internationale Domstol i forbindelse med høringerne om Kosovo. Jeg citerer igen: "Uafhængighedserklæringer kan, og sådan sker det ofte, krænke intern lovgivning. Det betyder dog ikke, at der sker en krænkelse af folkeretten." Citat slut. Det har de selv skrevet og udbasuneret over hele verden, de har overbevist alle, og nu er de sure. Hvorfor? Krimborgernes handlinger passer fint ind i denne instruktion, som man kan kalde den. Af en eller anden grund er det, som er muligt for albanerne i Kosovo (og dem respekterer vi), forbudt for russere, ukrainere og krimtatarer på Krim? Igen må man spørge: Hvorfor?

Fra USA og Europa hører vi, at Kosovo er en slags særtilfælde. Hvad gør det så unikt efter vores kollegers opfattelse? Det viser sig, at det består i, at der under konflikten i Kosovo var mange menneskelige ofre. Hvad er nu det? Et juridisk argument? I Den Internationale Domstols kendelse står der ikke noget herom. Der er ikke engang tale om dobbeltstandarder. Det er en forbløffende primitiv og ensidig kynisme. Man kan ikke tilpasse alt så groft til sine interesser og kalde den samme genstand hvid i dag og sort $\mathrm{i}$ morgen. Så skal man altså få enhver konflikt til at ende med menneskelige ofre.

Jeg vil gerne sige helt klart, at hvis de lokale selvforsvarsstyrker på Krim ikke havde taget situationen under kontrol i tide, ville der også kunne have været ofre dér. Gud være lovet, at det ikke skete. Der var ikke et eneste væbnet sammenstød på Krim og ingen menneskelige ofre. Hvorfor tror I, det forholdt sig sådan? Svaret er enkelt: Fordi det er vanskeligt eller praktisk talt umuligt at kæmpe mod folket og dets vilje. Og i denne forbindelse vil jeg gerne takke de ukrainske soldater, og det er et stort kontingent på 22.000 fuldt bevæbnede mand. Jeg vil gerne takke de ukrainske soldater, som ikke greb til blodsudgydelse og ikke sølede sig selv til i blod.
I denne forbindelse opstår der også andre tanker. Vi hører om en russisk intervention på Krim, om en aggression. Det lyder mærkeligt. Fra historien kan jeg ikke rigtig huske noget tilfælde, hvor en intervention er foregået uden et eneste skud og uden menneskelige ofre.

Ærede kolleger! I situationen omkring Ukraine afspejles det, der foregår nu og er foregået i verden i løbet af de seneste årtier. Efter det bipolare systems opløsning er der ikke blevet mere stabilitet i verden. De vigtigste internationale institutioner styrkes ikke, men svækkes desværre ofte. Vores vestlige partnere med USA i spidsen foretrækker ikke at lade sig lede af folkeretten i deres praktiske politik, men af den stærkes ret. De er kommet til at tro på, at de er særligt udvalgte, at de har lov til at afgøre verdens skæbne, at det altid kun er dem, der kan have ret. De handler, som det passer dem: så her, så dér anvender de magt mod suveræne stater og danner koalitioner efter princippet "den, der ikke er med os, er imod os." For at give aggressionen et skær af legitimitet får de de internationale organisationer til at vedtage de nødvendige resolutioner, og hvis det af forskellige årsager ikke lykkes, ignorerer de FN's Sikkerhedsråd og hele FN.

Det var det, der skete i Jugoslavien i 1999. Det var svært at tro, og jeg troede ikke mine egne øjne, men i slutningen af det 20. århundrede var en af Europas hovedstæder, Beograd, genstand for missilangreb i flere uger, og derefter fulgte en reel intervention. Var der en resolution fra FN's Sikkerhedsråd, der tillod sådanne handlinger? Ikke noget, der lignede. Senere kom både Afghanistan og Irak og de åbenlyse krænkelser af FN's Sikkerhedsråds resolution om Libyen, hvor man i stedet for at sikre den såkaldte flyveforbudszone også begyndte at bombardere.

Der var også en hel række "farvede" revolutioner. Det var forståeligt, at folk i de lande, hvor disse begivenheder fandt sted, var blevet trætte af tyranni, fattigdom og mang- 
lende perspektiver, men disse følelser blev ganske enkelt udnyttet kynisk. Disse lande blev påduttet standarder, som slet ikke passede til deres levevis og traditioner eller til disse folks kultur. Følgen var, at man i stedet for demokrati og frihed fik kaos, udbrud af vold og en række omvæltninger. "Det arabiske forår" blev afløst af "den arabiske vinter".

Et lignende scenarie udfoldede sig i Ukraine. For at presse den nødvendige kandidat igennem ved præsidentvalget i 2004 fandt man på en tredje valgrunde, der ikke var hjemlet i loven. Det var absurd og en forhånelse af forfatningen. $\mathrm{Og}$ nu har de indsat en i forvejen trænet og veludrustet hær af militante.

Vi forstår, hvad der foregår, forstår, at disse handlinger også var rettet mod Ukraine og Rusland og mod integrationen i det eurasiske rum. Og det på et tidspunkt, hvor Rusland var oprigtigt interesseret i dialog med vores kolleger i Vesten. Vi foreslår hele tiden samarbejde om alle vigtige spørgsmål, vi vil styrke tilliden, vi vil gerne have, at vores relationer er lige, åbne og ærlige. Men vi så ikke nogen imødekommenhed.

Tværtimod. Gang på gang har man bedraget os, truffet beslutninger bag vores ryg og stillet os over for en fuldbyrdet kendsgerning. Det skete ved NATO's udvidelse mod øst, med placeringen af militær infrastruktur ved vores grænser. Man blev ved at gentage: "Det vedrører ikke jer." Det var let nok at sige.

Sådan var det også med opstillingen af missilforsvarssystemerne. Trods alle vores betænkeligheder, er projektet sat i bevægelse. Sådan var det med forhandlingerne om visumproblemerne, der hele tiden blev trukket i langdrag. Sådan var det med løfterne om ærlig konkurrence og fri adgang til de globale markeder.

I dag truer man os med sanktioner, men vi lever i forvejen under en række begrænsninger og det endda nogle, der er meget væsentlige for os, for vores økonomi og for vores land. Allerede under den "kolde krig" forbød USA og siden også andre lande f.eks. at sælge en lang række teknologier og udstyr til USSR, idet man udarbejdede de såkaldte COCOM-lister. I dag er de formelt afskaffet, men kun formelt, for i virkeligheden gælder mange forbud stadigvæk.

Vi har kort sagt al mulig grund til at tro, at den infame afskrækkelsespolitik over for Rusland, som gennemførtes i det 18., 19. og 20. århundrede, fortsætter den dag i dag. Man prøver hele tiden at jage os op i et hjørne, fordi vi har en uafhængig holdning, fordi vi forsvarer den, fordi vi kalder tingene ved deres rette navn og ikke hykler. Men alt har sine grænser. Og i tilfældet med Ukraine har vores vestlige partnere krydset stregen og opført sig groft, uansvarligt og uprofessionelt.

De vidste jo udmærket, at der lever millioner af russere i Ukraine og på Krim. Hvor meget skal man miste af sin politiske fornemmelse og mådehold, før man ikke kan forudse alle følger af sine handlinger. Rusland stod på en linje, det ikke kunne trække sig tilbage fra. Hvis man trykker en fjeder helt sammen, vil den slå kraftigt tilbage på et tidspunkt. Det skal man altid huske.

I dag må hysteriet standses, man må give afkald på den "kolde krigs" retorik og anerkende en åbenlys ting: Rusland er en selvstændig, aktiv deltager i det internationale liv; det har som andre lande sine nationale interesser, som skal tages i betragtning og respekteres.

I denne forbindelse er vi taknemlige over for alle dem, der udviste forståelse for vores skridt på Krim, vi er taknemlige over for det kinesiske folk, hvis ledelse betragtede og betragter situationen omkring Ukraine og Krim i hele dens historiske og politiske kontekst, og vi sætter meget pris på Indiens tilbageholdenhed og objektivitet.

I dag vil jeg gerne henvende mig til USA's folk, til de mennesker, der siden grund- 
læggelsen af denne stat og vedtagelsen af uafhængighedserklæringen har været stolte af, at frihed for dem står over alt andet. Er Krimborgernes ønske om frit at kunne vælge deres skæbne ikke en sådan værdi? I må forstå os.

Jeg tror også, at europæerne, først og fremmest tyskerne, forstår mig. Jeg vil minde om, at det under de politiske konsultationer om foreningen af Forbundsrepublikken Tyskland og Den Tyske Demokratiske Republik, der foregik på ekspertniveau, men alligevel meget højt niveau, langt fra var alle lande, der er og dengang var Tysklands allierede, som støttede selve foreningsideen. Vores land, derimod, støttede helt klart tyskernes oprigtige, ubændige ønske om national enhed. Jeg er sikker på, at De ikke har glemt det, og regner med, at Tysklands borgere også vil støtte den russiske verdens, det historiske Ruslands ønske om genoprettelse af enhed.

Jeg vil også gerne henvende mig til det ukrainske folk. Jeg ønsker oprigtigt, at I forstår os: vi vil ikke under nogen omstændigheder gøre jer nogen skade eller krænke jeres nationale følelser. Vi har altid respekteret den ukrainske stats territoriale integritet til forskel fra dem, der har ofret Ukraines enhed for deres egne politiske ambitioner. De vigter sig med paroler om det store Ukraine, men netop de har gjort alt for at splitte landet. Den nuværende konfrontation mellem borgerne har de helt på deres samvittighed. Jeg vil gerne have, at I hører mig, kære venner. I skal ikke tro dem, der skræmmer jer med Rusland, og råber op om, at der følger andre regi- oner efter Krim. Vi ønsker ikke en deling af Ukraine, det har vi ikke brug for. Hvad angår Krim, så har den været og forbliver både russisk, ukrainsk og krimtatarisk.

Jeg vil gentage, at Krim, ligesom det har været tilfældet i århundreder, vil være det fælles hjem for repræsentanter for alle derboende folkeslag. Men den vil aldrig tilfalde Banderas tilhængere.

Krim er vores fælles historiske ejendom og den vigtigste faktor for stabilitet i regionen. Og dette strategiske territorium skal høre under en stærk og stabil suverænitet, som de facto i dag kun kan være russisk. Ellers, kære venner (jeg henvender mig både til Ukraine og til Rusland), vil vi - både russere og ukrainere - helt miste Krim, og det kunne ske i et nært historisk perspektiv. Tænk venligst over disse ord.

Jeg vil også minde om, at vi allerede har hørt erklæringer i Kijev om Ukraines snarlige indtræden i NATO. Hvad ville dette perspektiv betyde for Krim og Sevastopol? Det ville betyde, at NATO's flåde ville vise sig i den russiske krigeræres by, at der ville opstå en helt konkret og ikke blot forbigående trussel mod hele det sydlige Rusland. Alt dette ville reelt kunne ske, hvis ikke det havde været for krimborgernes valg. Det skal de have tak for.

Vi er i øvrigt ikke imod samarbejde med NATO, slet ikke. Vi er imod, at en militær alliance, og NATO, som er og bliver med alle dens indre processer en militær organisation, vi er imod, at en militær organisation gør, hvad der passer den, i nærheden af hegnet ind til os, ved siden af vores hus eller på vores historiske territorier. Jeg kan sim- 
pelthen ikke forestille mig, at vi skal tage til Sevastopol for at besøge NATO's matroser. De fleste af dem er såmænd pragtfulde drenge, men de må hellere komme på besøg hos os i Sevastopol, end vi hos dem.

Lad mig sige lige ud, at det smerter os dybt, hvad der nu sker i Ukraine, at folk lider, at de ikke ved, hvordan de skal leve i dag, og hvad der vil ske i morgen. Vores bekymring er forståelig, for vi er jo ikke bare nære naboer, vi er faktisk, som jeg har sagt det mange gange, ét folk. Kijev er de russiske byers moder. Oldrusland er vores fælles udgangspunkt, og vi kan ikke undvære hinanden.

Jeg vil også sige endnu en ting. I Ukraine lever der og vil leve millioner af russere, russisktalende borgere, og Rusland vil altid forsvare deres interesser med politiske, diplomatiske og juridiske midler. Men først og fremmest skal Ukraine selv være interesseret $i$, at disse menneskers rettigheder og interesser garanteres. Dette vil være et vidnesbyrd om den ukrainske stats stabilitet og landets territoriale integritet.

Vi ønsker venskab med Ukraine, vi ønsker, at Ukraine er en stærk, suveræn stat, der hviler i sig selv. For os er Ukraine jo en af de førende partnere, vi har mange fælles projekter, og uanset hvad tror jeg på deres succes. Og det vigtigste: vi ønsker, at der bliver fred og enighed i Ukraine, og vi er sammen med andre lande rede til at yde al mulig bistand og støtte. Men jeg gentager: Det er kun Ukraines borgere selv, der kan bringe orden i eget hus.

Ærede indbyggere på Krim og i Sevastopol! Hele Rusland har beundret jeres mod, værdighed og dristighed; det var netop jer, der afgjorde Krims skæbne. I disse dage har vi stået hinanden nær som aldrig før og støttet hinanden. Det var oprigtige solidariske følelser. Netop ved sådanne historiske vendepunkter sættes en nations åndelige modenhed og styrke på prøve. Og det russiske folk viste en så- dan modenhed og en sådan styrke med sin samlede støtte til sine landsmænd.

Ruslands faste udenrigspolitiske holdning byggede på millioner af menneskers vilje, på national enhed og på støtte fra ledende politiske og offentlige kræfter. Jeg vil gerne takke alle for denne patriotiske ånd, alle uden undtagelse. Men vi skal også fremover bevare en sådan konsolidering for at løse de opgaver, Rusland står overfor.

Vi vil helt klart støde på ydre modstand, men vi skal afgøre med os selv, om vi er rede til konsekvent at forsvare vores nationale interesser, eller om vi vil opgive dem for altid og trække os tilbage uvist hvorhen. Nogle vestlige politikere skræmmer os allerede ikke alene med sanktioner, men også med udsigten til en forværring af de interne problemer. Det kunne være rart at vide, hvad de tænker på: femtekolonneaktivitet fra forskellige "nationalforrædere", eller om de regner med at kunne forværre Ruslands social-økonomiske stilling og dermed fremprovokere folks utilfredshed? Vi finder sådanne erklæringer uansvarlige og klart aggressive og vil reagere herpå på passende vis. Samtidig vil vi selv aldrig søge konfrontation med vores partnere i Østen eller Vesten; vi vil tværtimod gøre alt, vi kan, for at opbygge civiliserede og gode naboforhold, som det sig hør og bør i den moderne verden.

Ærede kolleger! Jeg forstår krimborgerne, som har stillet spørgsmålet ved folkeafstemningen meget direkte og præcist: Skal Krim være med Ukraine eller med Rusland. Og man kan med overbevisning sige, at ledelsen af Krim og Sevastopol, medlemmerne af de lovgivende organer i formuleringen af spørgsmålet har hævet sig op over gruppeinteresser og politiske interesser og udelukkende sat folks fundamentale interesser som hjørnesten. Enhver anden variant af folkeafstemningen, hvor tiltrækkende den end måtte synes ved først blik, ville i kraft af historiske, demografiske, politiske 
og økonomiske særtræk ved dette territorium være midlertidig og skrøbelig og uundgåeligt føre til en videre tilspidsning af situationen omkring Krim og have afspejlet sig i folks liv på den mest frygtelige måde. Krimborgerne rejste spørgsmålet klart og kompromisløst og uden mellemtoner. Folkeafstemningen var åben og fair, og folk på Krim udtrykte klart og overbevisende deres vilje: De vil være sammen med Rusland.

Rusland skal også træffe en vanskelig beslutning under hensyntagen til hele mængden af interne og eksterne faktorer. Hvad mener folk i Rusland nu? Her er der som i ethvert demokratisk samfund forskellige synspunkter, men jeg vil godt understrege, at holdningen hos det absolutte flertal af borgerne er klar.

De kender de sidste sociologiske enqueter, som blev gennemført i Rusland for ganske nylig: $95 \%$ af borgerne mener, at Rusland skal forsvare russerne og repræsentanterne for andre nationaliteter, der bor på Krim, og deres interesser. $95 \%$. Og over $83 \%$ mener, at Rusland skal gøre dette, selvom en sådan holdning vil vanskeliggøre vores forhold til visse stater. 86 $\%$ af borgerne i vores land er overbeviste om, at Krim stadig er et russisk territorium, et russisk område. Og næsten - det er et meget vigtigt tal, der stemmer helt overens med resultatet af folkeafstemningen på Krim - næsten 92 \% går ind for Krims forening med Rusland.

Det overvældende flertal af borgerne på Krim og det absolutte flertal af borgerne i Den Russiske Føderation støtter således Republikken Krims og byen Sevastopols genforening med Rusland.

$\mathrm{Nu}$ er det op til Rusland selv at træffe en politisk beslutning. Og den kan kun bygge på folkets vilje, fordi kun folket er kilden til enhver myndighed.

Ærede medlemmer af Føderationsrådet! Ærede medlemmer af Statsdumaen! Borgere i Rusland, indbyggere på Krim og i Sevastopol! På grundlag af resultaterne af den folkeafstemning, der har fundet sted på Krim, og med støtte i folkets vilje fremlægger jeg for Forbundsforsamlingen en anmodning om at behandle en forfatningslov om optagelse af to nye subjekter i Den Russiske Føderation: Republikken Krim og byen Sevastopol, og ratificere aftalen om Republikken Krims og byen Sevastopols indtræden i Den Russiske Føderation, der er klar til undertegnelse. Jeg er ikke i tvivl om Deres støtte.

Oversat fra russisk af Lars P. Poulsen-Hansen 